\title{
PERANCANGAN KARYA ILUSTRASI GUNA PENGENALAN SISTEM IRIGASI SUBAK KEPADA MASYARAKAT MUDA DI PULAU BALI
}

\author{
1 I Gusti Ngurah Wahyu Parmadi, 2 Paku Kusuma
}

\author{
Universitas Telkom, Program Studi Desain Komunikasi Visual \\ Jl. Telekomunikasi No. 1, Dayeuh Kolot, Jawa Barat \\ ${ }^{1}$ wahyu@blim.us, ${ }^{2}$ does.sense@gmail.com
}

\begin{abstract}
ABSTRAK
Subak merupakan lembaga irigasi dan pertanian yang bercorak sosio-religius terutama bergerak dalam pengolahan air untuk produksi tanaman setahun khususnya padi berdasarkan prinsip Tri Hita Karana. Sebagai lembaga irigasi petani tradisional, subak diperkirakan sudah ada di Bali sejak hampir satu millenium. Saat ini minat generasi muda di pulau Bali terhadap pemahaman sistem subak lebih sekedar penamaan saja sehingga dalam beberapa kasus terjadi penutupan sekolah, lembaga pendidikan dan jurusan yang berkaitan dengan hal tersebut dikarenakan ketiadaan anak didik. Hal yang menjadi keprihatinan bagi berbagai kalangan, sehingga dalam penelitian ini dimaksudkan untuk mendapatkan pemahaman yang mendalam guna memperoleh nilai rasa dan karsa, kemudian diwujudkan secara visual melalui ilustrasi. Dimana hasil ilustrasi ini nantinya akan diaplikasikan ke media-media cetak seperti buku juga media elektronik untuk mendapatkan tanggapan yang lebih positip dari masyarakat muda di pulau Bali.
\end{abstract}

Kata Kunci: Subak, Tri Hita Karana, ilustrasi.

\begin{abstract}
Subak is an institute of irrigation and agriculture are patterned socio-religious mainly engaged in the processing of water for crop production, especially rice a year based on the principle of Tri Hita Karana. As an institution of traditional irrigation farmers, Subak expected already in Bali for almost a millennium. Currently the interest of the younger generation on the island of Bali to the understanding of the Subak system is more than naming it so that in some cases the closures of schools, educational institutions and departments relating to this case because of a lack of students. It is a matter of concern for many people, so in this study are intended to gain a deep understanding in order to obtain the value of feeling and intention, then manifested visually by way of illustration. Where the results of this illustration will be applied to the print media such as books also electronic media to get a more positive response from young people on the Bali island.
\end{abstract}

Keywords: Subak, Tri Hita Karana, Illustration. 


\section{PENDAHULUAN}

Subak merupakan lembaga irigasi dan pertanian yang bercorak sosio-religius terutama bergerak dalam pengolahan air untuk produksi tanaman setahun khususnya padi berdasarkan prinsip Tri Hita Karana (Sutawan,2002 : 80). Subak sebagai lembaga tradisional memang sudah di kenal di mancanegara. United Nation Education, Scientific and Cultural Organization (UNESCO), pada 12 juni 2012 menetapkan subak sebagai warisan budaya dunia dalam kategori lanskap budaya. Nama yang diberikan oleh UNESCO untuk warisan tersebut adalah "Cultural Landscape of Bali Province: the Subak System as a Manifestation of the Tri Hita Karana Philosophy" (Warisan Budaya Orang Bali: Subak sebagai Manifestasi dari Tri Hita Karana).

Sebagai organisasi yang mengurus tentang sistem irigasi tradisional, subak juga memiliki daya tarik tersendiri bagi wisatawan yaitu rice terrace (sawah berteras) yang umumnya tersusun atas petak sawah yang bertingkat-tingkat atau berundak-undak menyerupai anak tangga yang tidak berukuran, pemandangan itulah yang disuguhkan kepada para wisatawan baik lokal maupun mancanegara yang berkunjung ke Bali. Sebagai organisasi tradisional, subak juga memiliki aturan tertulis sebagai produk hukum yang disusun berdasarkan hasil musyawarah masyarakat subak yang disebut Awig-awig. Salah satu aturan tertulis pada Awig-awig menurut Sutawan pada buku ORGANISASI DAN MANAJEMEN SUBAK DI BALI adalah: "Pelanggaran yang berkaitan dengan bibit dan tanaman padi. Hal-hal yang termasuk dalam pelanggaran ini antara lain adalah: varitas bibit yang ditanam menyimpang dari kesepakatan subak atau tidak mengikuti perintah pengurus subak; mulai pembibitan melampaui batas waktu yang diperbolehkan misalnya dalam jangkau waktu selambatlambatnya 10 hari; mencuri bibit; mencabut tanaman padi milik orang lain; menanam padi pada waktu mendapat giliran menanam palawija; dan membakar jerami sampai mengakibatkan kebakaran tanaman padi milik orang lain; membuang jerami di sungai; menumpuk jerami di jalan subak".

Dalam menerapkan Awig-awig tersebut berlandaskan Tri Hita Karana sehingga keseimbangan antara Tuhan, manusia dan lingkungan tetap terjaga. Tri Hita Karana merupakan ajaran filosofi agama Hindu yang selalu ada dalam setiap aspek kehidupan masyarakat Bali. Istilah Tri Hita Karana adalah tiga penyebab kebahagiaan yang dapat dicapai dengan cara menjaga keharmonisan dalam Tri Hita Karana yaitu hubungan harmonis antara manusia dengan Tuhan (Parhyangan), hubungan harmonis antara manusia dengan sesama manusia (Pawongan) dan hubungan harmonis antara manusia dengan lingkungan (Palemahan). Tujuan Tri Hita Karana bagi masyarakat Bali sangat memberikan pengaruh yang besar terhadap aspek kehidupan mereka, maka dari itu subak sebagai sistem irigasi traditional Bali menerapkan konsep Tri Hita Karana dengan harapan akan tetap menjaga keseimbangan antara Tuhan, manusia, dan lingkungan.

Para leluhur nenek moyang petani di Bali mengimplementasikan Tri Hita Karana dalam subak sebagai cara yang efektif dalam mengintensifkan pertanian sawah di Bali. Hingga Subak bukan sekedar istilah budidaya, tetapi juga menjadi salah satu inti dari budaya Bali. Ritual dan spiritualnya. 
Budaya atau kebudayaan dalam subak mencakup pengetahuan, kepercayaan, seni, moral, hukum, adat-istiadat serta kebiasaan sekelompok masyarakat Bali. Selain itu, sebagai kebudayaan subak merupakan hasil karya, rasa dan cipta nenek moyang. Melalui cipta, rasa dan karya nenek moyang petani Bali telah mengembangkan subak menjadi organisasi tradisional yang memiliki nilainilai yang luar biasa, melewati batas etnis, bangsa agama dan kepercayaan. Berbagai nilai kemanusiaan diimplementasikan dalam bentuk yang luhur itu Tri Hita Karana. Tujuannya bukan hanya dalam mengelola siklus tanam padi. Namun yang jauh lebih penting, implementasi Tri Hita Karana bertujuan mengatur siklus kehidupan, agar manusia dapat hidup di bumi ini secara berkelanjutan (Kaler Surata, 2013:126).

Menurut Sutawan dalam buku ORGANISASI DAN MANAJEMEN SUBAK DI BALI "Masyarakat Bali pada umumnya sering menginterpretasikan subak dengan salah satu gambaran berikut, suatu kompleks persawahan; tentang luas dan batas-batas tertentu, para petani padi sawah yang terhimpun dalam satu wadah organisasi yang bergerak di bidang pengelolaan air irigasi, dan sistem fisik atau jaringan irigasi itu sendiri sebagai telabah (saluran-saluran), empelan (empangan air di sungai), tembuku (bangunan-bangunan pembagi air) dan fasilitas lainnya". Kurangnya pemahaman masyarakat Bali tentang subak membuat masyarakat Bali menginterpretasikan subak seperti itu. Pemahaman seperti itu tidaklah salah, akan tetapi kegiatan ritual anggota irigasi di Bali lebih dominan dibandingkan yang dilakukan petani di daerah-daerah lain sehingga dapat dikatakan kegiatan ritual yang terkait dengan tradisi dan agama Hindu di Bali itulah yang membedakan sistem irigasi di Bali dengan sistem irigasi di daerah lainnya. Pengenalan kembali mengenai konsep subak di Bali sangatlah penting untuk memperjelas pemahaman masyarakat Bali tentang subak terutama pembelajaran untuk generasi muda di Bali.

Subak dapat menjadi model yang tepat dan teruji bagi pembelajaran, karena mampu menghilangkan pembatas antara belajar di sekolah dan kehidupan nyata, antara ilmu alam dan ilmu sosial, antara sains modern dan sains tradisional, dan terutama pembatas antara generasi dan warisan kebudayaan leluhurnya. Sejarah perkembangan subak dapat memberikan fokus yang jelas tentang tantangan dalam mengimplementasikan suatu pembelajaran berbasis lingkungan lokal. Pada saat ini subak menghadapi berbagai ancaman. Ancaman yang paling serius adalah minat generasi muda untuk bekerja dalam bidang pertanian sangat rendah. Kesan bekerja sebagai petani yang identik dengan penghasilan rendah, suasana kerja yang kotor, dan kurang terdidik mengakibatkan sebagian besar generasi muda menjauhi budidaya bertani.

Tidak dapat dipungkiri bahwa kalangan generasi muda sekarang tidak tertarik dengan sektor pertanian. Hal ini menyebabkan kurangnya pemahaman generasi muda terhadap organisasi subak. Fenomena ini ditunjukan dengan semkin sedikitnya petani yang berusia muda, lembaga pendidikan pertanian baik tingkat menengah maupun perguruan tinggi sangat sedikit peminatnya. Bahkan beberapa pendidikan pertanian tingkat menengah sudah tutup karena tidak ada siswa. Berbagai upaya telah dilakukan pemerintah, salah satunya adalah dengan memberikan beasiswa kepada mahasiswa di berbagai perguruan tinggi bidang pertanian, 
termasuk di Universitas Udayana sebagai salah satu Perguruan Tinggi Negeri di Bali. Namun, hal itu saja tampaknya belum cukup karena mengenalkan dan memberikan pemahaman tentang sistem subak sebagai tradisi budaya masyarakat Bali yang harus dipertahankan mestinya juga dilakukan dengan kesatuan konsep wacana dan aplikasi berbagai media (Windia, 2012:58).

\section{TINJAUAN TEORITIK}

Metode yang digunakan adalah metode penelitian kualitatif, dimana hal ini penting mengingat ilustrasi yang akan digali harus mempunyai kesamaan roh visual dengan masyarakat muda yang ada di pulau Bali. Menurut Bogdan dan Taylor (1975:5) metodelogi kualitatif adalah prosedur penelitian yang menghasilkan data deskriptif berupa kata-kata tertulis atau lisan dari orang-orang dan prilaku yang diamati. Berikut ini langkah-langkah yang diambil dalam pengumpulan data \& Analsis:

\section{Observasi dan wawancara}

Pengumpulan data yang dilakukan dengan cara mengamati, mencatat, dan turun langsung kepada anggota organisasi subak di Bali. Melebur dalam rangkaian proses pengkaryaan mereka dengan harapan bisa mencari data pengetahuan lebih mendalam dan menemukan bentuk dasar-dasar visual yang diperlukan dalam pembentukan ilustrasi dan perancangan format buku tentang subak dan implementasi Tri Hita Karana.

Penelitian juga dilakukan dengan cara melakukan kegiatan wawancara tatap muka kepada narasumber seperti masyarakat, pekaseh (ketua subak), petugas museum subak dan para saudara yang terlibat langsung dalam obyek penelitian.

\section{Studi literatur}

Mencari data dan informasi melalui buku-buku dan jurnal yang berkaitan dengan topik pembahasan, diantaranya: Buku TRI HITA KARANA menurut konsep Hindu, Lanskap Budaya Subak, SUBAK WARISAN BUDAYA DUNIA, ORGANISASI DAN MANAJEMEN SUBAK DI BALI.

\subsection{Ilustrasi}

Menurut Kusrianto (2007: 110) Ilustrasi secara harafiah berarti gambar yang dipergunakan untuk menerangkan atau mengisi sesuatu. Ilustrasi merupakan unsur grafis yang sangat vital dan dapat disajikan mulai dari goresan atau titik sederhana sampai dengan yang kompleks, ilustrasi merupakan subjek tersendiri yang memiliki alur sejarah serta perkembangan yang spesifik atas jenis kegiatan seni. Ilustrasi dapat dipergunakan untuk menampilkan banyak hal serta berfungsi antara lain:

- Memberikan gambaran tokoh atau karakter dalam cerita.

- Menampilkan beberapa contoh item yang diterangkan dalam suatu buku (text book).

- Menarik perhatian pembaca.

- Merangsang minat pembaca terhadap keseluruhan pesan.

- Menonjolkan keistimewaan dari produk.

- Menciptakan suasana khas.

- Dramatisasi pesan.

\subsection{Layout}

Menurut Pujrianto, 2005:71, Layout adalah usaha untuk menyusun, menata dan memadukan unsur-unsur komunikasi grafis menjadi media komunikasi visual yang 
komunikatif, estetik, persuasif, menarik perhatian dan mendukung pencapaian tujuan secara cepat dan tepat.

Gaya layout menurut Graham Davis dalam Kusrianto (2007: 289) yang nanti bisa dipergunakan dalam perancangan:

\section{1). Style Juvenile}

Juvenile adalah istilah buku untuk anakanak (walaupun style itu tidak dimaksudkan untuk anak-anak). Layout dibuat dengan kesan meriah dengan memasang gambar secara tersebar. Di antara kolom diberi garis pemisah dengan warna yang lemah. Headlines dan Subhead disusun menggunakan huruf kapital berukuran lebih besar untuk menarik perhatian.

\section{2). Style Youthful}

Style youthful memiliki kesan lucu, main-main, serta menyenangkan. Pada style tersebut digunakan unsur gambar serta pilihan font yang mendukung. Penulisan headline dilakukan menggunakan huruf dengan berbagai ukuran.

\subsection{Warna}

Warna merupakan pelengkap gambar serta mewakili suasana kejiwaan pelukisnya dalam berkomunikasi. Warna juga merupakan unsur yang sangat tajam untuk menyentuh kepekaan pengelihatan sehingga mampu merangsang munculnya rasa haru, sedih, gembira, mood atau semangat. Secara visual, warna memiliki kekuatan yang mampu mempengaruhi citra orang yang melihatnya (Kusrianto, 2007; 46). Masing-masing warna mampu memberikan respons secara psikologis. Molly E. Holzschlag, seorang pakar tentang warna, dalam tulisannya "Creating Color
Scheme" membuat daftar mengenai kemampuan masing-masing warna ketika memberikan respons secara psikologis kepada pemirsanya.

Warna Pada Masyarakat Bali

\begin{tabular}{|c|c|c|}
\hline Ireng & $=$ & Hitam \\
\hline Badeng kolot & $=$ & Hitam legam \\
\hline Bang & $=$ & Merah \\
\hline Barak ngakak & $=$ & Merah menyala \\
\hline Barak wayah & $=$ & Merah tua \\
\hline Gadang mude & $=$ & Hijau muda \\
\hline Abu-abu & $=$ & $\mathrm{Abu}$ \\
\hline Kuning & $=$ & Kuning \\
\hline Coklat & $=$ & Coklat \\
\hline Badeng & $=$ & Hitam \\
\hline Barak & $=$ & Merah \\
\hline Biing & $=$ & Merah cerah \\
\hline Barak ngude/dadu & $=$ & Merah muda \\
\hline Gadang & $=$ & Hijau \\
\hline Jingge & $=$ & Jingga \\
\hline Biru mude & $=$ & Biru muda \\
\hline Kuning mude & $=$ & Kuning mude \\
\hline Brumbun & $=$ & $\begin{array}{l}\text { Warna hasil } \\
\text { pencampuran } \\
\text { antara putih, } \\
\text { hitam, merah } \\
\text { dan kuning }\end{array}$ \\
\hline
\end{tabular}

\section{PEMBAHASAN}

Cara pengenalan dan memberikan pemahaman tentang sistem atau organisasi subak kepada masyarakat muda di pulau Bali telah dilakukan dengan cara membuat buku yang menjelaskan tentang subak tersebut. Buku formal yang telah ada menjelaskan segala perihal tentang subak. Namun, karena buku yang terkesan formal tersebut membuat kalangan muda kurang tertarik untuk membaca dan memahami isi buku tersebut. Remaja awal yaitu SMP (Sekolah Menengah Pertama) dan lingkup 
perguruan tinggi melakukan pembelajaran lebih banyak menggunakan materi buku dan menurut mereka akan lebih mudah memahami isi buku jika terdapat ilustrasi penjelas sebagai penunjang dari isi buku tersebut. Bukan sekedar gambar olahan karya fotografi saja tetapi juga wujud ilustrasi yang bisa mengembangkan imajinasi mereka.

\subsection{Sejarah Subak}

Bercocok tanam padi pada lahan sawah beririgasi merupakan aktivitas yang tidak terpisahkan dari keberadaan subak. Dari beberapa sumber, rupanya kegiatan bercocok tanam padi sudah ada di Bali sekitar tahun 882 Masehi karena kata huma yang berarti sawah telah disebutkan dalam prasasti tertua di Bali yakni prasasti Sukawana A1 (Purwita, 1993:42) dalam Sutawan (2008:9). Kata sawah bisa berarti lahan sawah tadah hujan, tetapi mungkin juga lahan sawah beririgasi (sawah basah). Menurut kamus Indonesia-Inggris karangan John M.Echols dan Hassan Shadily (1989), kata huma diterjemahkan sebagai field for dry rice cultivation atau lahan kering untuk bercocok tanam padi. Jadi, dapat disamakan dengan lahan sawah yang tidak beririgasi tetapi mengandalkan air hujan saja (sawah tadah hujan). Apabila kata huma yang dimaksud oleh prasasti Sukawana itu adalah memang benar lahan sawah basah, ini berarti bahwa irigasi mempunyai sejarah sangat panjang yang sudah diterapkan oleh petani-petani di Bali sejak lebih dari 1.000 tahun yang lampau.

Bahwa kata huma mungkin memang benar yang dimaksud adalah lahan sawah beririgasi (lahan sawah basah) terbukti dari adanya kata undagi pengarung yang tertulis dalam prasasti Bebetin A1 (896 Masehi) yang berarti tukang pembuat terowongan (arungan/aungan). Selanjutnya, dari prasasti Pandak Badung tahun 1071 Masehi juga sudah terdapat kata kasuwakan yang selanjutnya menjadi kasubakan atau subak (Purwita, 1993:42). Bahwa di Bali secara faktual sudah dikenal adanya sistem irigasi yang disebut kasubakan atau subak pada tahun 1071 Masehi ternyata diperkuat lagi oleh prasasti Klungkung tahun 1072 Masehi di mana telah disebutkan nama sebuah subak yaitu subak rawas. Dalam Prasasti Klungkung tersebut tertulis kalimat: "...masukatang huma di kedandan di errara di kasuwakan rawas..." yang artinya...." mengukur sawah di Kadandan pada Yeh Aya dalam wilayah subak rawas..." (Callenfels, 1926) dalam Purwita (1993:41). Kenyataan ini dapat lebih menyakinkan lagi bahwa memang benar huma itu berada di wilayah subak yang bernama subak rawas. Bukti lainnya yang mendukungh bahwa kata huma bukan berarti lahan kering atau sawah tadah hujan adalah terdapatnya kata parlak yang juga tercantum dalam prasasti Sukawana AI bertahun 882 Masehi tersebut yang diterjemahkan sebagai "tegalan" (kebun) (Purwita, 1993:40) dalam Sutawan (2008:10).

Selain dari Prasati Pandak Badung dan Prasati klungkung di atas, kata kasuwakan yang berarti wilauah subak juga ditemukan di beberapa prasasti lainnya seperti Prasasti Trunyan (881 M), Prasasti Sukawana (882 M), Prasati Bebetin A1 (896 M), prasasti Buwahan, Timpag dan Bugbug (Suadnya, 1990:2) dalam Sutawan (2008:11). Sementara itu, Dinas Pekerjaan Umum Propinsi Bali (1997:4) mengemukakan bahwa pada beberapa prasasti (namun tidak disebutkan nama prasastinya) yang ditulis secara abad ke-10 dan ke-11 telah dijumpai selain istilah kasuwakan (subak) juga istilah-sitilah lain seperti pekaser atau makaser (yang berarti kepala subak), 
patajur atau petajuh (wakil kepala subak), tembuku galeng (empangan), dan kilan (ukuran pembagian air).

Di pihak lain, naskah lontar yang memuat tentang sejarah perkembangan Hinduisme di Bali ("Kawit Babad Agama Hindu Wenten Ring Bali") disebutkan bahwa Rsi Markandeya datang ke Bali dari Gunung Rawung di Jawa Timur sekitar abad ke-12 untuk menyebarkan agama Hindu. Dalam lontar tersebut dijumpai kalimat "sang mikukuhang sawah kewastanin subak, sang mikukuhang toya kewastanin pekaseh, ika mawenang mengepah toya punika". Artinya, karena lebih "orang-orang yang aktif menggarap sawah dinamakan anggota subak, orang yang mengatur distribusi air disebut pekaseh, mereka semua bertanggung jawab dalam pembagian air antara anggota subak".

Dapat disimpulkan bahwa petani-
petani setempat telah memiliki
keterampilan berorganisasi yang cukup mengesankan dalam mengerahkan sumberdaya dan menciptakan aturanaturan yang disepakati bersama demi mewujudkan keadilan, rasa kebersamaan, persatuan dan kesatuan di kalangan para petani anggota subak. Mereka juga telah memiliki keterampilan teknis untuk mengelola air irigasi secara cermat. Kearifan lokal tersebut diperoleh secara turun temurun dari nenek moyang mereka yang ditularkan secara informal.

\subsection{Tri Hita Karana}

Dalam kitab suci agama Hindu sangat mudah didapatkan petunjuk bagaimana umat Hindu melakukan hubungan dengan Tuhan melalui jalan Bhakti. Demikian juga cara umat menciptakan hubungan yang harmonis dengan sesama manusia dan bagaimana melakukan upaya untuk memelihara dan menjaga kesejahteraan alam lingkungan. Ajaran yang mengajarkan umat manusia untuk menciptakan hubungan yang harmonis dengan Tuhan, dengan sesama manusia dan dengan alam lingkungan, maka akan terwujud kehidupan yang bahagia lahir batin. Tiga hubungan yang harmonis itulah yang disebut dengan ajaran Tri Hita Karana.

Secara etimologis bahasa Sansekerta, istilah Tri Hita Karana berasal dari kata "tri, hita dan karana". Tri artinya tiga, Hita artinya bahagia dan Karana artinya penyebab. Dengan demikian Tri Hita Karana sebagai istilah berarti "tiga penyebab kebahagiaan". Nama Tri Hita Karana inilah yang dijadikan judul untuk menyebutkan ajaran yang mengajarkan agar manusia mengupayakan hubungan harmonis dengan Tuhan (Parhyangan), sesama manusia (Pawongan) dan juga alam lingkungannya (Palemahan) (Wiana, 2007:5).

\section{Parhyangan}

Penataan Parhyangan untuk memelihara eksistensi lingkungan rohani sebagai media untuk berbakti pada Tuhan.

\section{Pawongan}

Penataan Pawongan untuk menjaga eksistensi lingkungan sosial agar umat manusia hidup untuk saling mengabdi sesuai dengan swadharmanya.

\section{Palemahan}

Penataan Palemahan untuk menjaga eksistensi lingkungan alam agar senantiasa menjadi sumber kehidupan dan penghidupan semua makhluk hidup di isi alam ini. 
Tiga lingkungan hidup ini harus dijaga keseimbangan eksistensinya agar terus berlangsung secara berkelanjutan. Kalau terjadi kepincangan atau kesenjangan diantara ketiga lingkungan itu maka kondisi membangun hidup bahagia atau Hita Purusha tujuan utama Tri Hita Karana akan menjadi terhalang (Wiana, 2007: 23).

\subsubsection{Parhyangan}

Unsur pertama dari Tri Hita Karana adalah Parhyangan. Parhyangan menata hubungan antara manusia dan Tuhan Yang Maha Esa. Manusia adalah ciptaaan Tuhan. Atman (jiwa) yang dimiliki manuisa merupakan percikan suci dari kebesaran Tuhan. Manusia berhutang nyawa pada Tuhan. Dengan demikian, manusia wajib berterimakasih dengan berbakti kepada Tuhan (Surata, 2013: 8) Orang Bali menyakini bahwa setiap gejala dan kejadian selalu memiliki dua aspek, yaitu aspek sekala dan niskala. Sekala adalah aspek nyata yang bisa dilihat atau dibuktikan dengan indera manusia. Niskala merupakan aspek yang tidak nyata, tetapi kekuatan dan pengaruhnya bisa dirasakan oleh mereka yang menyakininya. Banyak masalah kehidupan tidak dapat diselesaikan hanya dengan menggunakan aspek sekala. Parhyangan adalah aspek niskala untuk membuat hubungan yang lebih dekat dengan Tuhan, sebagai pencipta alam semesta dan segala isinya.

Unsur Parhyangan dalam subak terdiri atas berbagai pura dan beragam upacara untuk memelihara hubungan harmonis dengan Tuhan. Nama pura bisa berbeda antara satu subak, dan subak yang lain. Beberapa dari pura tersebut adalah:

a. Pura Ulun Danu
Pura yang berlokasi pada empat danau yang ada di Bali, yaitu Danau Batur di Kabupaten Bangli, Danau Beratan di Kabupaten Tabanan, Danau Buyan dan Danau Tamblingan di Kabupaten Buleleng.

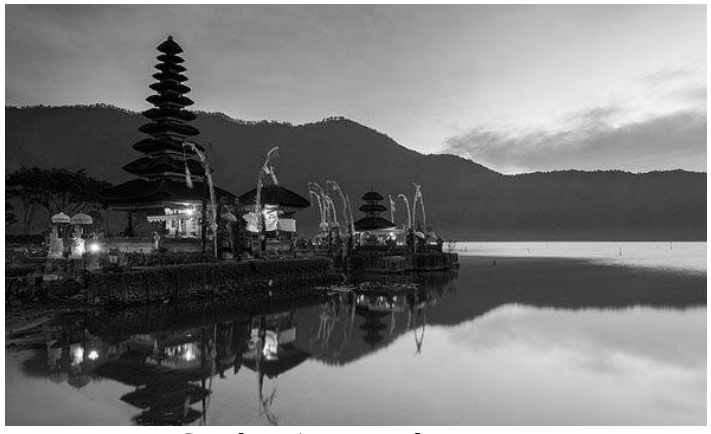

Gambar 1 Pura Ulun Danu Sumber: http://www.baliglory.com

b. Pura Ulun Suwi

Dibangun pada wilayah subak tertentu atau beberapa subak yang menggunakan air dari sumber air yang sama.

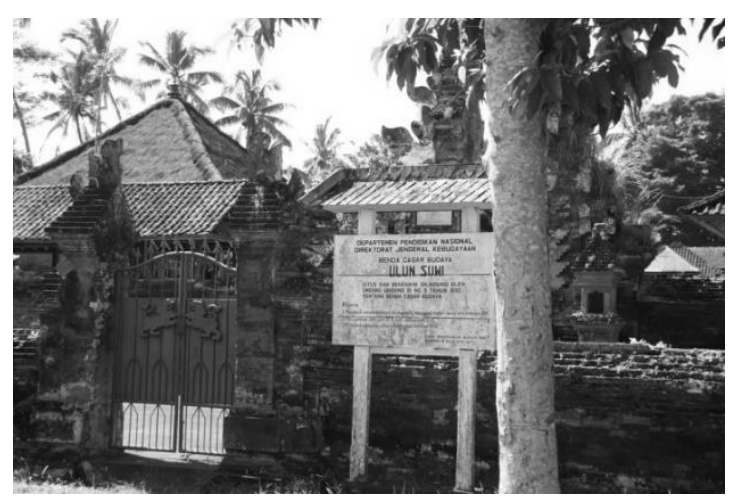

Gambar 2 Pura Ulun Suwi Sumber: http://static.panoramio.com/

c. Pura Masceti

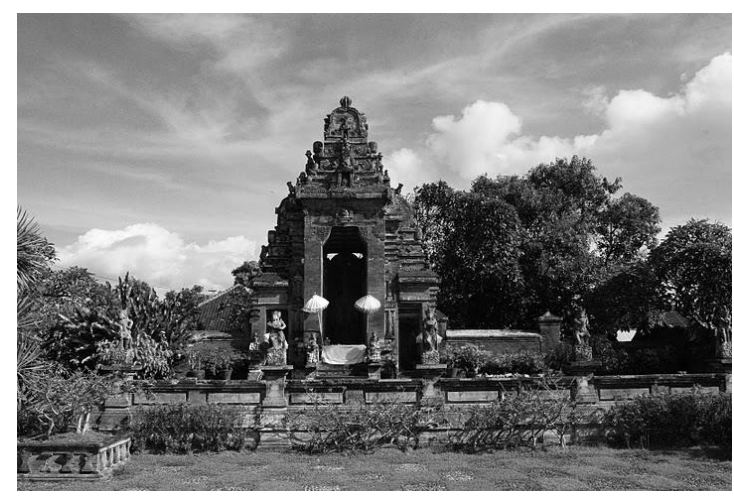

Gambar 3. Pura Masceti Sumber: http://bali.panduanwisata.id/ 
Pura yang umumnya dibangun pada bagian hilir subak, misalnya di dekat pantai.

\section{d. Pura Empelan}

Pura yang dibangun dekat bendungan atau tempat pembagian air.

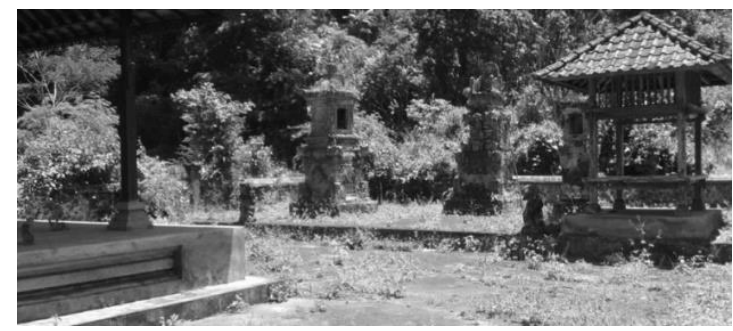

Gambar 4. Pura Empelan Taman Sari Sumber: http://balitribune.co.id/

e. Sanggah Catu

Bangunan yang dibuat oleh petani di dekat air irigasi masuk ke sawah mereka.

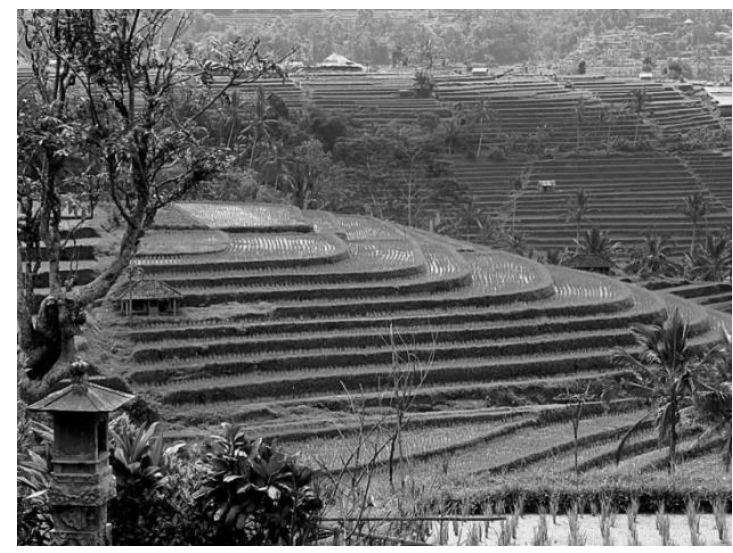

Gambar 5. Sanggah Catu

Sumber: panbelog.files.wordpress.com

\section{Upacara Keagamaan Pada Sistem Subak}

Kegiatan upacara agama merupakan salah satu wujud implementasi Tri Hita Karana dalam konteks parhyangan, yaitu keselarasan hubungan manusia dengan Tuhan. Di organisasi subak terdapat beberapa jenis upacara yang harus dilaksanakan sebagai wujud bakti dan rasa syukur anggota subak atas segala nikmat dan kemurahan yang diberikan oleh Tuhan. Upacara tersebut antara lain sebagai berikut:

\section{a. Mapag Toyo}

Uparaca ini bertujuan untuk menjemput air irigasi untuk dialirkan ke wilayah subak agar usaha tani yang akan dilakukan anggota subak dapat terlaksana dengan baik. Upacara ini biasanya dilakukan didepan bendungan air setiap subak.

\section{b. Ngendangin}

Upacara ini dilakukan apabila anggota subak akan memulai melakukan kegiatan bertani. Bertujuan untuk memohon izin di hulu sawah, serta untuk memohon anugerah Tuhan, dalam manifestasinya sebagai Betara Sri pemberi kehidupan warga subak.

\section{c. Ngurit}

Ngurit atau mawiwih pantun (membenihkan padi) adalah upacara yang dipersembahkan pada saat pembenihan.

\section{d. Ngerasikan}

Yaitu upacara yang dilaksanakan setelah selesai meratakan sawah sebelum padi ditanam.

\section{e. Nandur}

Sebelum melakukan kegiatan menanam padi pastikan sawah tempat memelihara padi sudah dalam keadaan baik dan bersih. Menggunakan waktu yang baik untuk menanam padi, disesuaikan dengan keadaan setempat yang perhitungannya menggunakan hitungan hari yang disebut dengan mitra satru, yaitu sesuai dengan hari kelahiran masing-masing warga subak.

\section{f. Padi berumur satu bulan}

Jika padi telah berumur satu bulan, atau telah tumbuh tiga ruas diandaikan sebagai 
anak yang telah lincah pada saat itu dilaksanakan upacara yang bertujuan untuk menghaturkan rasa syukur bahwa tanaman padi yang ditanam dapat tumbuh dengan baik dan di harapkan dapat memberikan hasil yang baik.

g. Padi berumur dua bulan

Upacara ini juga bertujuan untuk menyampaikan rasa syukur dan terimakasih kepada Tuhan atas kemurahanya sehingga padi yang ditanam dapat tumbuh dan berkembang dengan baik.

h. Padi berumur tiga bulan

Padi yang berumur tiga bulan disamakan dengan manusia yang telah memiliki keinginan mengejar kesenangan, karena telah akil balik (remaja).

\section{i. Padi meikuh lasan}

Upacara saat padi sudah keluar malai, sehingga tampak seperti ekor kadal (ikuh lasan). Upacara ini bertujuan agar padi yang telah keluar malai dapat berkembang dengan baik, sehingga dapat segera di panen.

\section{j. Memanen padi}

Memanen padi dan merias nini kaki dan nini manuh, merupakan wujud bakti kepada Dewi Sri, sebagai bukti telah berhasilnya kegiatan bertani.

\section{k. Mantenin}

Mantenin adalah mengupacarai padi di lumbung, bertujuan untuk menyampaikan rasa syukur bahwa benih padi yang ditanam kini telah menghasilkan dan dapat disimpan untuk memenuhi kebutuhan hingga musim panen berikutnya.

\subsubsection{Pawongan}

Pawongan merupakan elemen kedua dari Tri Hita Karana. Pawongan adalah hubungan harmonis antara sesama manusia. Manusia merupakan makhluk social sehingga tidak dapat hidup tanpa manusia lainnya. Manusia harus berinteraksi dengan sesama manusia dan menjadi bagian dari sistem sosial. Agar tercapainya kebahagiaan, kemakmuran dan kesejahteraan kehidupan, maka setiap orang perlu memelihara hubungan harmonis dengan orang lainnya (Surata, 2013: 16).

\section{Krama (anggota) Subak}

Unsur Pawongan dari subak terdiri atas krama subak, organisasi subak dan peraturan-peraturan atau awig-awig. Karama subak bisa berasal dari satu desa yang sama, atau dapat pula berasal dari beberapa desa yang berbeda-beda. Hal itu tergantung pada luas wilayah subak. Subak berukuran kecil biasanya memiliki karma yang berasal dari satu desa di dekatnya. Sebaiknya subak dengan lahan sawah yang luas pada umumnya memiliki karma subak dari beberapa desa di sekitarnya. Secara umum anggota subak atau krama subak dibedakan menjadi tiga, yaitu:

\section{Krama pengayah (anggota aktif)}

Krama subak yang secara aktif terlibat dalam kegiatan subak seperti upacara keagamaan, gotong-rotong pemeliharaan dan perbaikan fasilitas subak dan sangkepan (rapat) subak. 


\section{Krama Pengampel atau Krama Pengoot (anggota pasif)}

Krama subak yang karena alasan tertentu tidak terlibat secara aktif dalam ayah-ayahan (berbagai kegiatan sosial) subak. Sebagai gantinya anggota ini membayar dengan sejumlah beras atau uang yang disebut pengoot atau pengampel.

\section{Krama Leluputan (anggota khusus)}

Krama subak yang dibebaskan dari berbagai kewajiban subak, karena yang bersangkutan memegang jabatan tertentu di dalam masyarakat seperti pemangku (pinandita di sebuh pura), bendesa adat (pimpinan desa adat), perbekel (kepala desa), ataupun sulinggih (pendeta, peranda, Sri Mpu dan lain-lain).

\section{Organisasi Subak}

Organisasi subak bervariasi tergantung pada ukuran subak. Subak kecil biasanya memiliki susunan organisasi yang sederhana sebaliknya subak yang besar mempunyai susunan organisasi yang kompleks. Unsur pengurus subak disebut prajuru subak. Prajuru subak terdiri atas pekaseh (ketua subak), petajuh (wakil), penyarikan (sekretaris) dan patengen atau juru raksa (bendahara). Prajuru tersebut dipilih oleh anggota subak untuk masa jabatan tertentu (misalnya empat atau lima tahun). Kasinoman atau juru arah atau juru unduh merupakan jabatan yang dipegang secara bergilir oleh krama subak dengan masa tugas 35 hari atau 210 hari, sesuai dengan perhitungan penanggalan tradisional Bali. Kasinoman bertugas untuk memberikan arahan, menyampaikan atau mengumumkan kegiatan, serta kewajiban yang harus dipenuhi atau diikuti oleh krama subak.

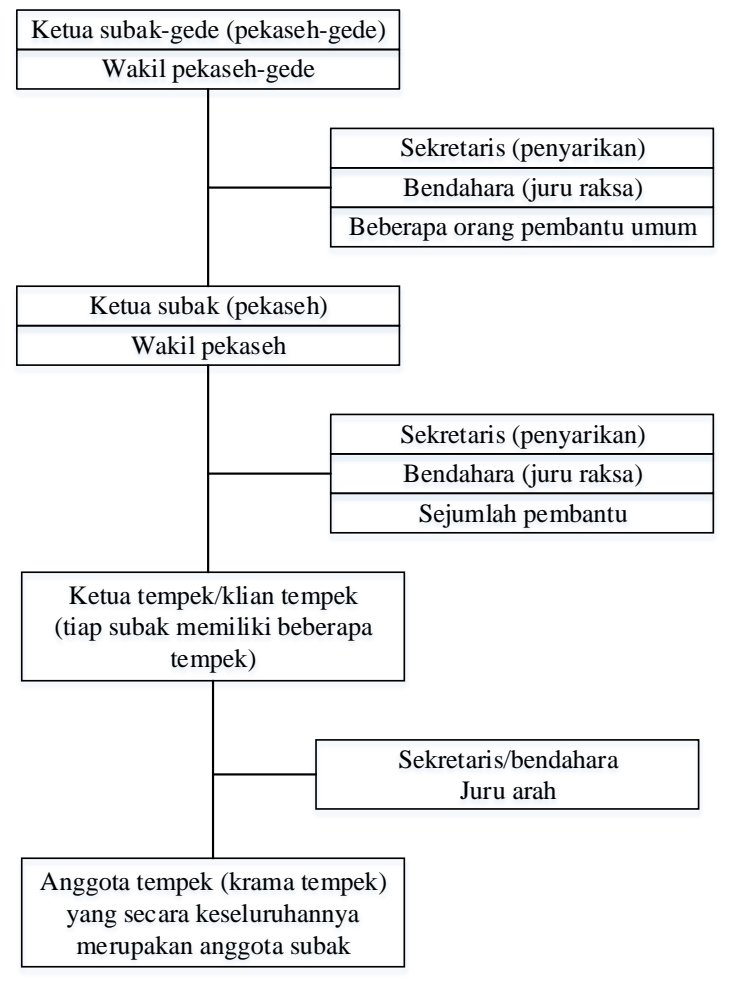

Gambar 6. Struktur Organisasi Subak Sumber: (Sutawan, 2008: 110)

Salah satu kegiatan penting dalam organisasi subak adalah sangkepan. Sangkepan atau rapat bagi krama subak dilakukan setiap 35 hari sesuai dengan kalender orang Bali. Waktu penyelenggaraan sangkepan dipilih pada hari yang dipandang baik menurut kalender Bali. Misalnya Buda Umanis, Anggara kasih atau Saniscara Kliwon.

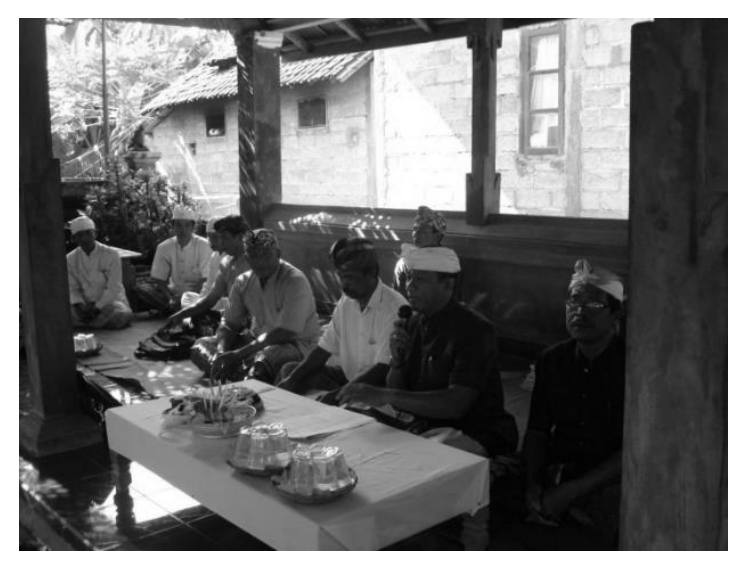

Gambar 7. Sangkepan (rapat) Sumber: camatsawan.blogspot.com 
Sangkepan dipimpin oleh pekaseh dan prajuru subak lainya. Kegiatan itu selalu diawali dengan ngaturang canang (memberikan sesajen) kepada Tuhan agar beliau berkenan memberikan bimbingan sehingga sangkepan bisa berlangsung sesuai dengan harapan krama subak. Berbagai hail dibahas dalam sangkepan, mulai dari petanggungjawaban bidang keuangan, kegiatan upacara keagamaan, masalah dalam pertanian sampai dengan pelanggaran terhadap awig-awig. Sejak dahulu kala, sangkepan dikenal mengutamakan dan mendorong penerapan konsep kehidupan berdemokrasi yang sehat. Sangkepan mengutamakan prinsip menyama braya (hidup rukun sebgai saudara), sangilik-sanguluk salulungsabayantaka (kebersamaan, kerjasama, tolong menolong dan berbagai bersama) dan paras-paros sarpanaya (berdinamika dalam keberagaman).

Kegiatan lain dalam subak adalah gotong-royong, yaitu bekerja bersama secara sukarela dalam menyelesaikan pekerjaan tertentu. Misalnya setelah upacara mapag toya (upacara yang mengawali masuknya ir ke saluran irigasi dan lahan sawah), maka krama subak secara bergotong-royong memperbaiki dan membersihkan saluran irigasi agar air mengalir dengan lancar ke sawah mereka.

\section{Awig-awig Dalam Subak}

Awig-awig adalah produk hukum dari subak yang disusun berdasarkan hasil musyawarah mufakat oleh krama subak. Subak merupakan salah satu dari organisasi adat. Oleh karena itu awig-awig merupakan produk hukum dari subak, maka awig-awig merupakan hukum adat. Awig-awig dibuat secara tertulis dan menjadi pedoman bertingkah laku bagi krama subak. Awig- awig disusun berdasarkan filsafat tri hita karana. Isi awig-awig mengatur hubungan antara krama subak dan Tuhan, antara sesama krama subak, dan antara krama subak dan lingkungan. Unsur parhyangan dalam awig-awig biasanya mencakup tentang kahyangan (pura) dan pengaci (upacara keagamaan) yang menjadi tanggung jawab sebuah subak. Pawongan mengatur tentang krama (anggota), prajuru (pimpinan), sangkepan (rapat), kulkul (kentongan), padruweyan (hak milik) dan bhaya (bencana). Unsur palemahan meliputi wates (batas wilayah), tetanduran (tanaman), wewangunan (bangunan), toya (air), dan merana (hama dan penyakit) tanaman. Disamping itu dalam awig-awig juga dimuat tentang pihak yang berwenang menyelesaikan permasalahan dan denda atau sangsi bagi yang melanggar awig-awig.

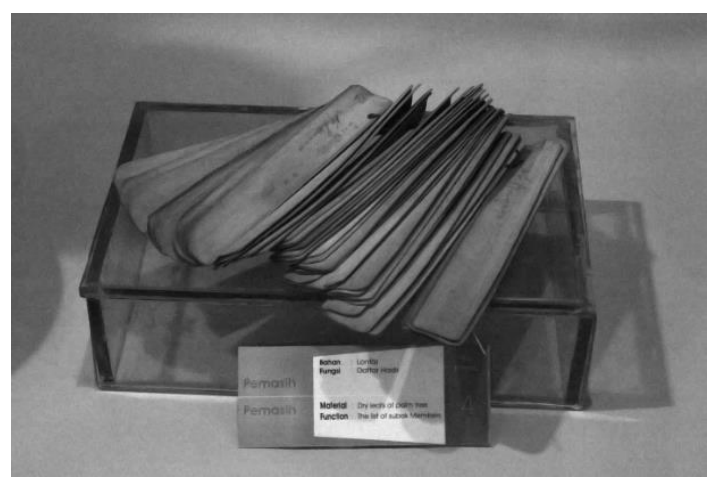

Gambar 8. awig-awig berbentuk lontar Sumber foto: dokumentasi I Gusti Wahyu Parmadi

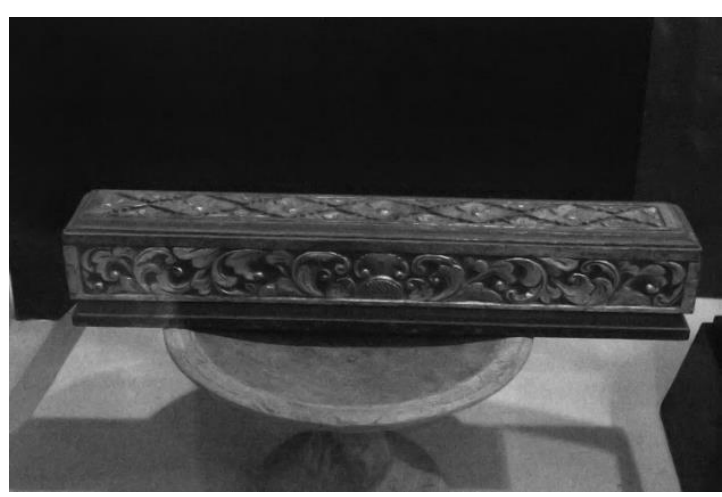

Gambar 9. Wadah (tempat) awig-awig Sumber foto: dokumentasi Wahyu Parmadi 
Paswara atau perarem merupakan aturan pelaksana awig-awig. Misalnya dalam perarem diatur kesepakatan tentang berat atau ringanya hukuman atau denda bagi yang melanggar awig-awig. Perarem dapat berubah sesuai dengan keadaan atau keputusan dalam sangkepan.

\subsubsection{Palemahan}

Palemahan berasal dari kata "lemah" yang berarti nyata. Palemahan dalam konsep Tri Hita Karana adalah hubungan harmonis antara manusia dan alam lingkungannya. Unsur Palemahan dalam subak mencakup benda mati, makhluk hidup dan lanskap subak. Sesuai dengan konsep Hindu di Bali, benda mati disebut Panca Mahabutha yaitu lima unsur dasar pembentuk kehidupan. Sedangkan keanekaragaman mahluk hidup dikenal sebagai Sarwa Prani atau sebagai jenis bentuk kehidupan.

\section{Lanskap Subak Berteras}

Lanskap subak atau panorama subak di Bali telah terkenal ke seluruh dunia. Lanskap tersebut pada umumnya tersusun atas petak sawah yang bertingkat-tingkat atau berundak-undak menyerupai anak tangga dengan ukuran yang tidak beraturan. Keadaan sawah seperti itu disebut sawah berteras. Sawah berteras terbentang hampir di seluruh pelosok Pulau Bali, mulai dari pegunungan, jurang, lembah, sisi kanan dan kiri sungai.

Sawah tersebut dibangun mengikuti kontur kawasan sekitarnya. Kontur adalah semacam garis mendatar atau horisontal yang melengkung mengikutu ketinggian dan kemiringan daerah sekitarnya. Sawah berteras yang tersusun dari puluhan atau bahkan ratusan petak sawah, nampak seperti kumpulan garis yang tersusun rapi, berundak-undak dan berkelok-kelok menyerupai lukisan atau ukiran.

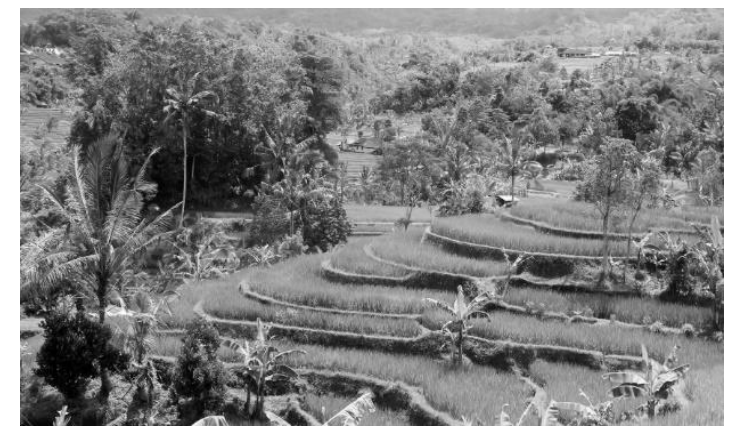

Gambar 10. Lanskap subak berteras Sumber: en.wikipedia.org

Beberapa pengamat menyatakan nenek moyang orang Bali bukan hanya mengukir kayu dan batu tetapi juga tebing, jurang dan tanah. Pernyataan itu mempertegas pendapat bahwa sawah berteras juga sebagai karya seni orang Bali. Tidak heran jika banyak wisatawan mancanegara dan wisatawan nusantara menjadikan lanskap sawah berteras sebagai salah satu tujuan kunjungan mereka ke Bali.

Perlu diketahui sawah berteras tidak saja terdapat di Pulau Bali, tetapi bisa pula ditemukan pada berbagai daerah lainnya. Misalnya sawah berteras di Indonesia dapat dijumpai di Kabupaten Manggarai Tengah di Pulau Flores, kawasan sekitar Toraja di Sulawesi Selatan dan berbagai propinsi di Pulau Jawa. Sawah berteras juga terdapat di luar negeri. Salah satu yang terkenal adalah sawah berteras di Filipina. Bahkan kawasan sawah tersebut sudah diakui sebagai warisan dunia oleh Badan Dunia untuk Pendidikan dan Kebudayaan ( UNESCO ).

Tentu saja keindahan panorama sawah berteras pada kawasan yang telah disebutkan di atas tidak kalah menarik dengan lanskap di Bali. Para petani di sana juga mempraktekkan budidaya atau bercocok tanam padi dengan berbagai teknologi tepat guna. Tetapi lanskap subak 
di Bali memiliki keunikan yang tidak ditemukan pada kawasan lanskap sawah di daerah lainnya. Petani di Bali bukan hanya melakukan kegiatan "budidaya" bertani. Meraka juga melaksanakan aktivitas "budaya" yang senantiasa berjalan seiring dengan kegiataan budidaya

\section{Bangunan Irigasi}

Bagunan utama yang ada dalam subak adalah bangunan saluran irigasi. Hal ini sesuai dengan sejarah subak.nama subak berasal dari kata kasuwakan atau saluran air. Bangunan irigasi subak terdiri atas empelan (bendungan), telabah (saluran air), tembuku (bangunan bagi air) dan bangunan pelengkap

\section{a. Empelan}

Empelan atau bendungan dibangun untuk membendung air sungai dan mengalirkanya ke areal persawahan. Ukuran bendungan bervariasi, ada bendungan kecil yang hanya digunakan oleh satu subak, sebaliknya ada juga bendungan besar yang digunakan oleh beberapa subak.

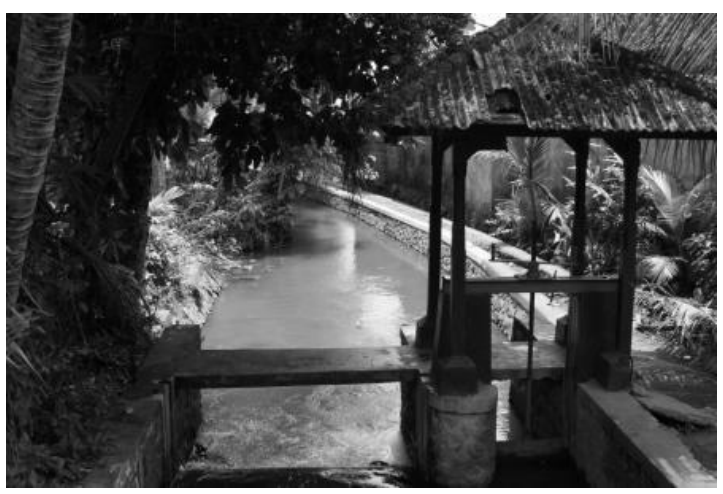

Gambar 11. Empelan (bendungan) Sumber gambar: pemetaanttg.com

\section{b. Telabah}

Telabah adalah saluran yang menyalurkan air langsung dari bendungan.

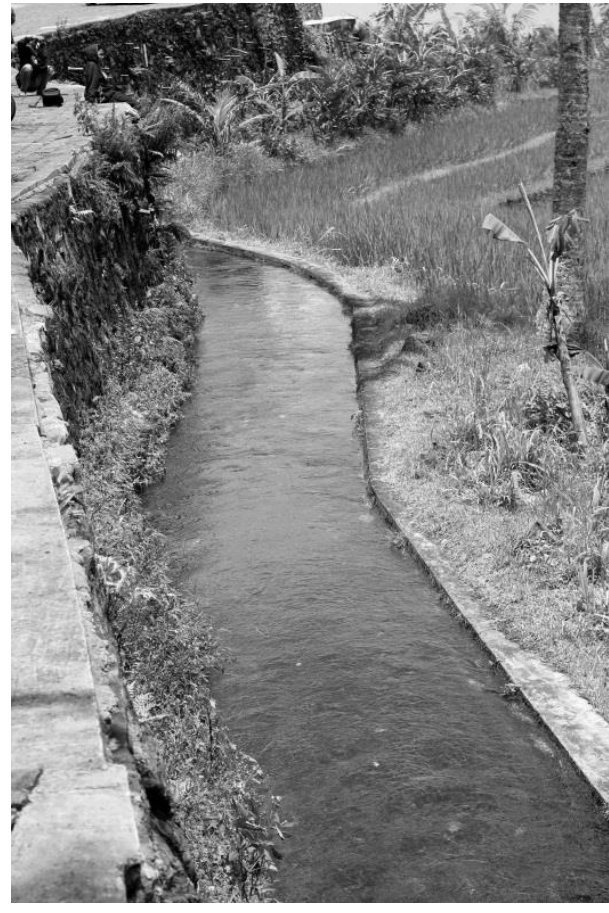

Gambar 12. Telabah (saluran air)

Sumber foto: dokumentasi Wahyu Parmadi

\section{c. Tembuku}

Tembuku atau bangunan bagi air diberikan nama sesuai dengan nama saluran air di sebelah hulunya. Misalnya tembuku aya untuk bangunan yang membagi air dari telabah aya ke telabah gede. Sedangkan tembuku gede, membagi air dari telabah gede ke telabah cerik.

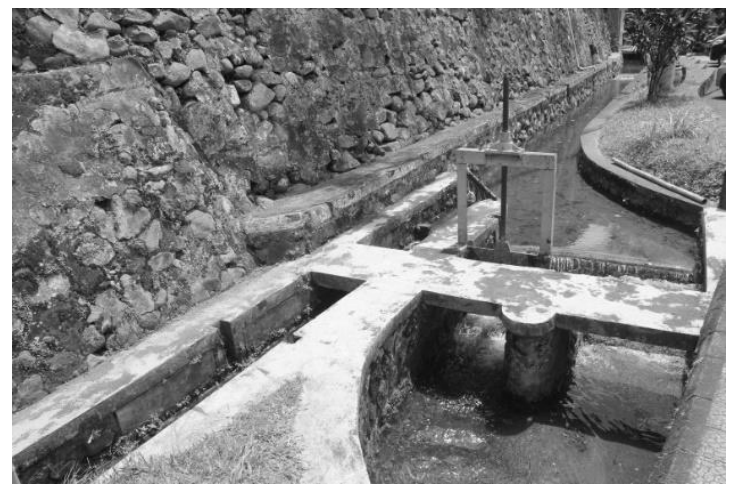

Gambar 13. Tembuku (pembagi air) Sumber foto: dokumentasi Wahyu Parmadi

\section{d. Pengalapan}

Pengalapan air irigasi yang masuk ke sawah petani melalui petak sawah. Pengalapan berasal dari kata ngalap atau 
memanen. Pengalapan adalah lahan sawah tempat petani ngalap (memanen) air irigasi. Oleh karena itu, pengalapan merupakan lahan sawah yang paling utama. Pada setiap pengalapan terdapat sebuah pelinggih atau bangunan suci yang disebut Sanggah Catu.

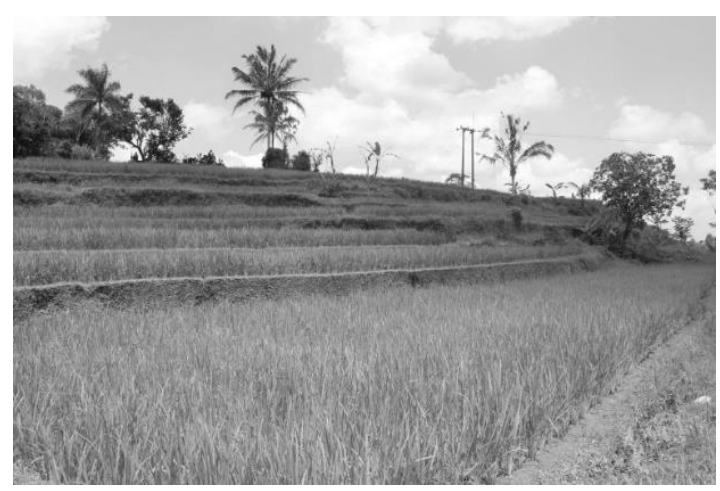

Gambar 14. Pengalapan (petak sawah) Sumber: dokumentasi Wahyu Parmadi

\subsection{Analisis Visual}

Khalayak sasaran kalangan muda di pulau Bali memiliki karakteristik yang mirip dengan daerah lainnya secara psikologis, dimana sangat penting untuk diperkenalkan tentang budaya karena diusia ini bangkitnya akal (ratio), nalar (reason), dan kesadaran diri (self consciousness). Anak dianjurkan belajar tentang alam dan kesenian, tapi yang penting adalah proses belajarnya, bukan hasilnya. Anak akan belajar dengan sendirinya, karena periode ini mencerminkan era perkembangan ilmu pengetahuan dalam evolusi manusia (Sarwono, 2013:28). Dalam usia muda ini terdapat energi dan kekuatan fisik yang luar biasa serta tumbuh keingintahuan. Dalam periode ini, disarankan untuk membaca buku berilustrasi yang bisa memudahkan pengenalan dan pemahaman.

1. Khalayak memiliki gaya hidup mengikuti tren di lingkunganya, selalu belajar, terbuka, suka berbagi cerita, unik, pengetahuan, berpikiran terbuka, senang berbagi cerita.

2. Khalayak memiliki kepribadian rasa ingin tahu yang besar, santai, menyukai adat dan budaya, aktif, berpikiran luas, mudah bersosialisasi.

3. Ilustrasi dianggap mampu menarik perhatian pembaca atau merangsang minat pembaca terhadap keseluruhan pesan serta menonjolkan keistimewaan dari produk.

4. Menggunakan komunikasi visual sehingga segala sesuatu yang dapat dilihat dapat dipakai untuk menyampaikan arti, makna, atau pesan.

Kesimpulan di atas dapat dianalisis dalam bentuk visual dengan referensi visual yang telah didapat. Dari unsur-unsur visual dan data yang telah didapat, dapat dianalisa unsur-unsur desain komunikasi visual yang digunakan yaitu:

\begin{tabular}{|c|c|l|}
\hline No. & Unsur-unsur visual & \multicolumn{1}{c|}{ Hasil analisa } \\
\hline 1 & Ilustrasi & $\begin{array}{l}\text { Menggunakan ilustrasi simpel dengan teknik } \\
\text { pewarnaan menggunakan cat air. } \\
\text { Menggunakan gaya ilustrasi Indonesia yang } \\
\text { menampilkan ilustrasi dengan gerture wajah, } \\
\text { pakaian, gerak-gerik, maupun lingkungan yang khas } \\
\text { dengan Indonesia itu sendiri. } \\
\text { Teknik ilustrasi yang } \\
\text { digunakan adalah teknik hand drawing yaitu teknik } \\
\text { mengganbar yang hampir keseluruhanya } \\
\text { menggunakan tangan. }\end{array}$ \\
\hline 2 & Tipografi & $\begin{array}{l}\text { Menggunakan karakter tipografi yang tidak kaku } \\
\text { sepelu jenis hurur tulis dan dekoratif, Serta } \\
\text { jenis monospace agar terlihat playful }\end{array}$ \\
\hline 3 & I.ayout & $\begin{array}{l}\text { Menggunakan style layout juveline dan youthful } \\
\text { karena pada layout ini menggambarkan sifat } \\
\text { khalayak sasaran. }\end{array}$ \\
\hline
\end{tabular}

Tabel 1. Analisis Unsur-unsur Desain Komunikasi Visual

Dari referensi visual dan data dapat dianalisa unsur-unsur visual yang akan digunakan sebagai berikut: 


\begin{tabular}{|c|c|c|c|}
\hline No. & Unsur-unsur visual & Hasil analisa & Keterangan gambar \\
\hline 1 & Warna & $\begin{array}{l}\text { Susunan warna di Bali } \\
\text { Rajah Nawasanga } \\
\text { (sembilan warna) yaitu } \\
\text { hitam, biru, putih, dadu } \\
\text { (merah muda), merah, } \\
\text { jingga, kuning, hijau dan } \\
\text { brumbun (campuran warna). }\end{array}$ & \\
\hline 2 & Garis & $\begin{array}{l}\text { Lengkung, gelombang } \\
\text { diambil dari refrensi dan } \\
\text { bentuk lanskap subak yang } \\
\text { bergelombang. }\end{array}$ & $\mathrm{C}_{\mathrm{x}=\mathrm{C}}^{\mathrm{C}} \mathrm{x}-2 \mathrm{x}$ \\
\hline 3 & Bentuk/bidang & $\begin{array}{l}\text { Non-geometri yaitu tidak } \\
\text { beraturan }\end{array}$ & \\
\hline
\end{tabular}

Tabel 2. Analisis Unsur-unsur Visual

Analisis visual tersebut dirancang agar informasi dalam perancangan ilustrasi dapat tersampaikan dengan baik kepada target pasar. Hasil analisa kemudian akan dijadikan landasan dalam merancang ilustrasi yang dimulai dari pembuatan sketsa dan pewarnaan digital dengan konsep parhyangan yaitu hubungan antara manusia dengan Tuhan.

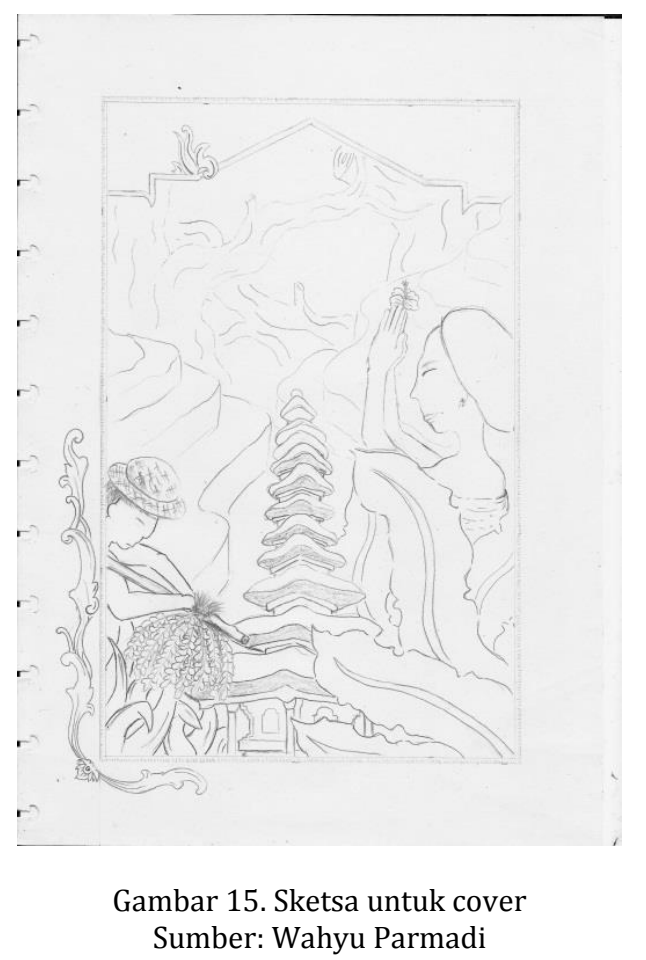

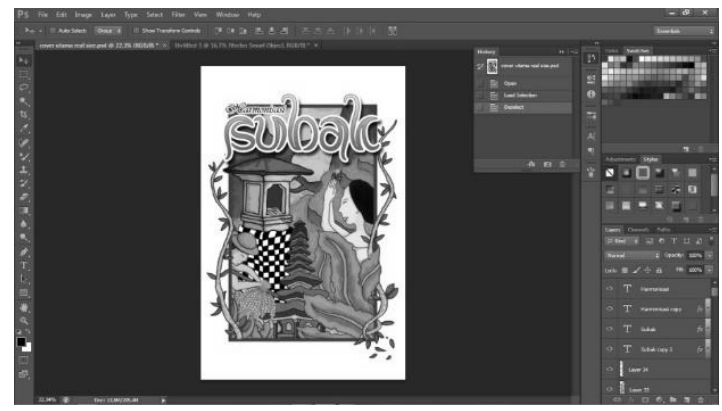

Gambar 16. Hasil olah digital (Photoshop) Sumber: Wahyu Parmadi

Lalu sketsa dan digital untuk ilustrasi pawongan (hubungan antara sesama manusia) dan palemahan (hubungan manusia dengan lingkungan). Pada ilustrasi pawongan menggunakan konsep sangkepan (rapat) dimana yang ditunjukan adalah suasana anggota subak yang sedang sangkepan dengan latar lanskap subak dan bangunan Bali. Ilustrasi yang diwujudkan berupaya membangun kebersamaan dan suasana yang harmonis.

Sedangkan pada penggarapan ilustrasi palemahan menggunakan konsep anggota subak yang sedang membajak sawah, cerminan hubungan harmonis manusia dengan alam lingkungannya. 


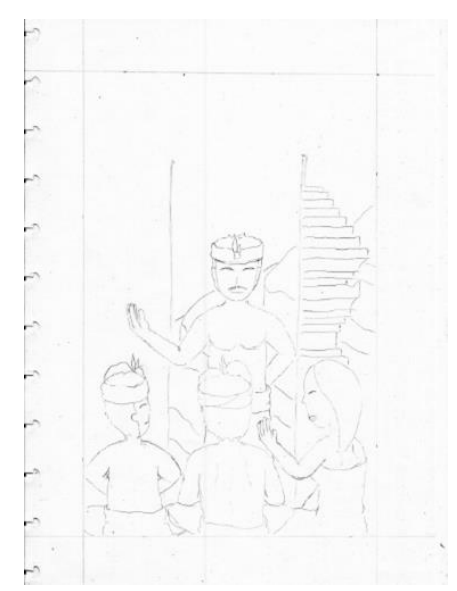

Gambar 16. Sketsa untuk ilustrasi pawongan Sumber: Wahyu Parmadi

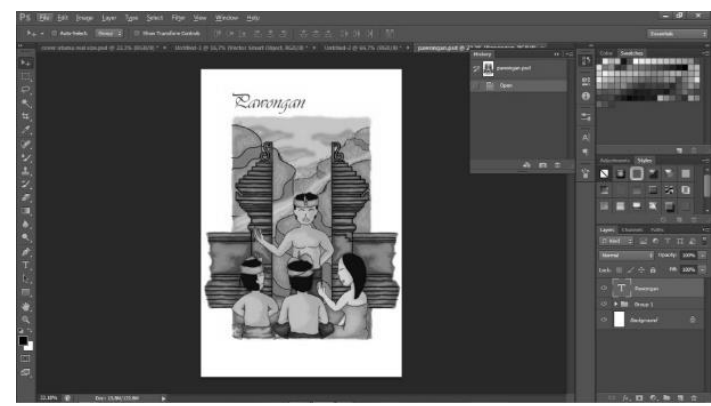

Gambar 17. Hasil digital ilustrasi Pawongan Sumber: Wahyu Parmadi

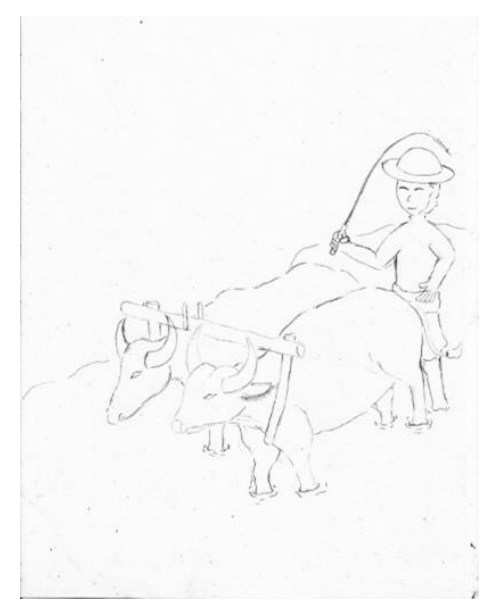

Gambar 18. Sketsa ilustrasi Palemahan Sumber: Wahyu Parmadi

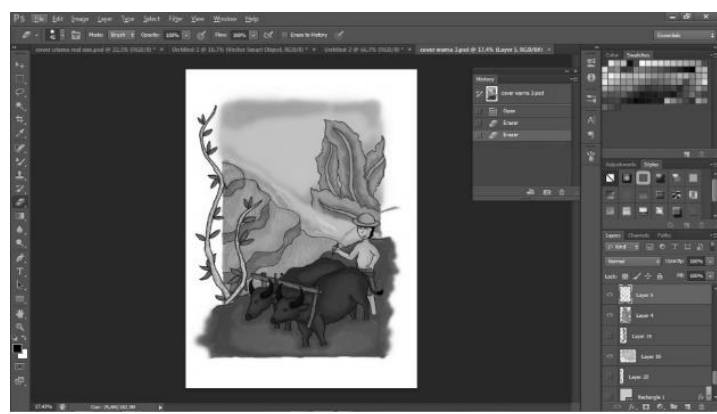

Gambar 19. Hasil digital ilustrasi Palemahan Sumber: Wahyu Parmadi

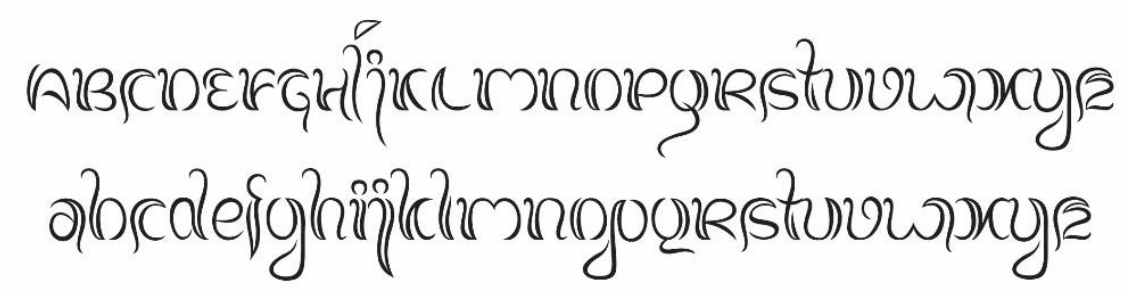

111

Gambar 20. Karakter jenis huruf Balinese Family

Tipografi yang digunakan dalam perancangan akan disesuaikan konsep yang telah di jelaskan. Font yang digunakan pada bagian penambah keterangan utama (headline) di ilustrasi diambil dari konsep aksara Bali yaitu Balinese Family.

Jenis font kedua adalah jenis font hand write yang digunakan pada setiap keterangan yang ditambahkan setelah penggunaan headline. Font yang dipilih adalah Vivaldi.

Jenis font ketiga adalah jenis font yang terkesan bermain untuk menarik perhatian dari target pasar, memudahkan untuk pembacaan dan masih memiliki kejelasan yang maksimal. Font yang digunakan untuk penulisan body text ini adalah Juice ITC. 


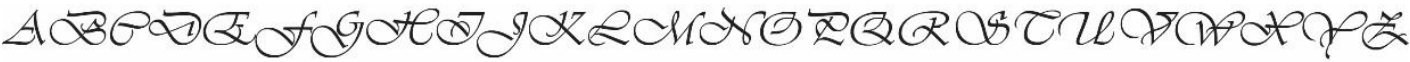 abodefghijklmnopqrstuvwoxpz ..':[]!@\# $8 \% \wedge \& \mathbb{E}^{*}()_{-}+=<>?$ ?"}

Gambar 21. Karakter jenis huruf Vivaldi

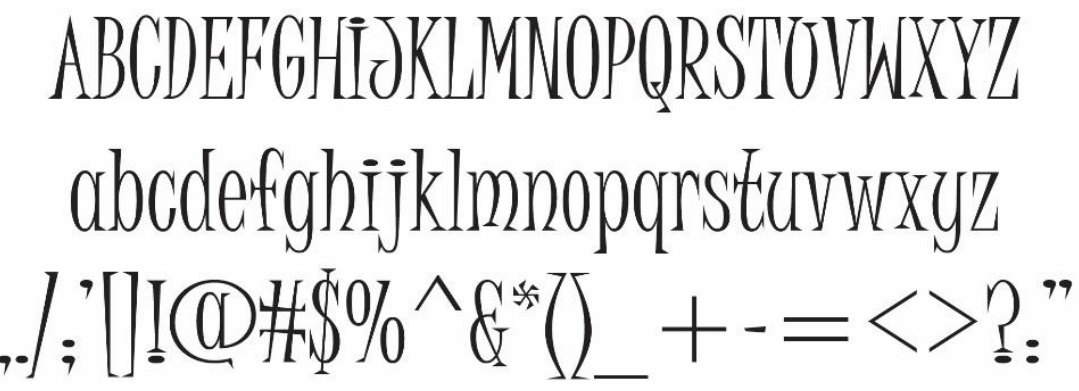

Gambar 22. Karakter jenis huruf Juice ITC

\section{Ilustrasi Karakter}

Ilustrasi karakter yang digunakan dalam perancangan ini berdasarkan hasil observasi dan analisis yaitu karakter yang disukai oleh kalangan generasi muda saat ini di Bali. Selain menggunakan karakter penggambaran dari remaja dan anak muda di Bali, hal ini juga memiliki tujuan untuk membangun rasa memiliki, kebersamaan dan kedalaman rasa yang sama karena pada dasarnya memiliki ruh yang sama pula.

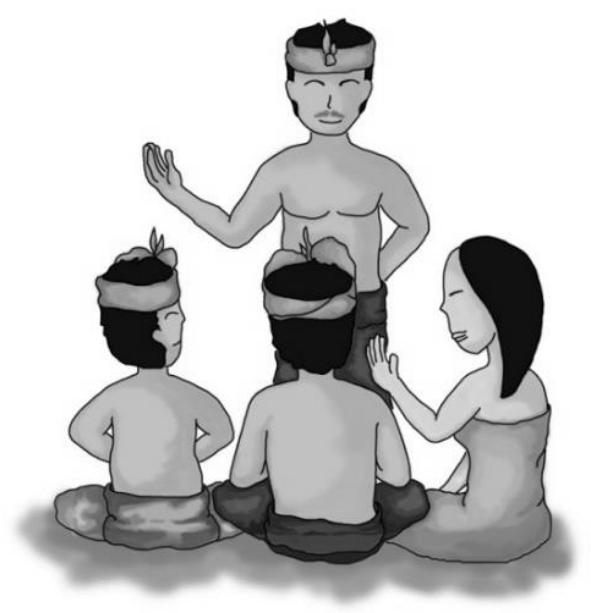

Gambar 23. Karakter ilustrasi anak muda di Bali. Sumber gambar: I Gusti Ngurah Wahyu Parmadi
Ilustrasi karakter nanti menggunakan warna-warna yang cerah agar terkesan lebih ceria dan unsur bermain. Dengan menggunakan budaya lokal yaitu pakaian adat Bali sebagai ciri khas dari ilustrasi karakter ini. Seperti yang telah dijelaskan, konsep untuk penggambarannya adalah hand drawing dengan pewarnaan digital. Pewarnaan digital disini dimaksudkan sebagai inovasi dari pewarnaan yang digunakan dalam pembuatan ilustrasi.

\section{Background (Layout)}

Background yang digunakan dalam ilustrasi adalah penggambaran lanskap subak atau sawah berteras sesuai dengan usnsur Tri Hita Karana yaitu palemahan yang didalamnya terdapat lanskap subak atau sawah berteras. Pada background konten menggunakan warna putih dari kertas karena putih membangun kecermatan agar pembaca terfokus pada isi konten dan ilustrasi sebagai penjelas konten. Layout yang digunakan adalah style juvenile dan youthful, style ini sama-sama memberi kesan bermain dengan menggunakan pilihan gambar dan font yang mendukung. 


\section{KESIMPULAN/RINGKASAN}

Berdasarkan fenomena yang tampak sudah seharusnya pemerintahlah yang mempunyai peranan kuat untuk program ini, baik pemerintah pusat dan pemerintah daerah pada khususnya. Jika pemerintah tanggap untuk ikut serta mendukung penyebaran informasi dengan langkah dan jalan yang berbeda melalui perancangan ilustrasi ini maka nantinya bisa dijadikan acuan untuk pengembangan dan pelestarian organisasi subak yang lebih bisa diterima oleh masyarakat muda di Bali. Hal ini agar masyarakat terutama generasi muda paham akan adanya warisan budaya dunia ini, sehingga mereka dapat ikut serta dalam pelestarian warisan budaya dunia ini.

Anak muda sebagai penerus generasi memberi kontribusi besar dan pengaruh terhadap kelangsungan warisan budaya dunia subak ini. Remaja mengalami masa yang kritis, mempunyai rasa ingin tahu yang tinggi, sehingga melalui upaya pengenalan dengan perancangan ilustrasi yang nantinya diaplikasikan ke berbagai media pendukung mampu membantu memberikan informasi atau mengenalkan kembali tentang budaya subak dan implementasi tri hita karana yang ada didalamnya. Hal ini agar senantiasa remaja bali tahu akan warisan budaya dunia yang mereka miliki dan melestarikannya hingga ke generasi-generasi selanjutnya di Bali.

Masyarakat di pulau Bali yang memang terkenal sebagai gudangnya para seniman dan pengrajin karya seni yang terkenal di dunia karena terbentuk dari lingkungan sedari kecil dan ciri khas religinya ternyata belum mampu mengadopsi hal tersebut dengan maksimal terlebih dengan kaitannya kepada masyarakat mudanya. Ilustrasi sebagai daya tarik pemahaman dasar belum diterapkan dalam media yang berkaitan erat dengan para remaja. Merancang sebuah konsep ilustrasi dan penggambaran karakter visual dengan tema utama Harmonisasi Subak ini diharapkan menarik perhatian remaja Bali untuk setidaknya mengenal lebih dalam dan mau ikut serta mengembangkan ketahanan pangan di daerahnya dan melestarikan sistem pertanian yang memang menjadi tradisi budaya adiluhung. 


\section{DAFTAR PUSTAKA}

[1] Adi Kusrianto, 2007, Pengantar Desain Komunikasi Visual, Andi offset: Yogyakarta.

[2] Brazell, D., Davies, J., 2013, Becoming a Successful Illustrator. Bloomsbury: New York.

[3] Didit Widiatmoko, 2013, Metodologi Penelitian Visual, Dinamika Komunika: Bandung.

[4] Indiria Maharsi, 2011, Komik Dunia Kreatif Tanpa Batas, Kata Buku: Yogyakarta.

[5] Kuno, Naomi, 2004, Tasteful color combinations, Page one: Singapore.

[6] Male, A., 2007, illustration, AVA Publishing SA.: Switzerland.

[7] Moleong, L., 2012, Metodologi Penelitian Kualitatif, Remaja Rosdakarya: Bandung.

[8] Otani, N., 2014, Creative Techniques of Fashion Illustration, Design Media Publishing Limited: Hong Kong.

[9] Pujiriyanto, 2005, Desain Grafis Komputer, Andi offset: Yogyakarta.

[10] Sanjaya, W., 2012, Media Komunikasi Pembelajaran, Kencana: Jakarta.

[11] Sarwono, S., 2013, Psikologi Remaja, Rajawali Pers: Jakarta.

[12] Surata, S.K., 2013, Landskap Budaya Subak, UNMAS Press: Denpasar.

[13] Surianto Rustan, 2009, Layout dan dasar penerapannya, Gramedia Pustaka Utama: Jakarta.

[14] Suta, I.A., 2010, Arts through the intelligence of a child, The Ary Suta Center: Denpasar

[15] Sutawan, N., 2008, Organisasi dan manajemen subak di Bali, Pustaka Bali post: Bali.

[16] Tillman, B. (2011). Creative Character Design. Kidlington: Focal Press.

[17] Wiana, I., 2007, Tri Hita Karana menurut konsep Hindu, Paramitha: Surabaya.

[18] Windia, W., 2012, Subak Warisan budaya dunia, Udayana University Press: Denpasar. 